\section{Regards sur l'économie allemande}

Bulletin économique du CIRAC

$75 \mid 2006$

Varia

\title{
Droit européen
}

MÄHNER Tobias, Der Europäische Gerichtshof als Gericht

\section{OpenEdition}

\section{Journals}

Édition électronique

URL : http://journals.openedition.org/rea/493

DOI : $10.4000 /$ rea.493

ISBN : 978-2-8218-0846-1

ISSN : 1965-0787

\section{Éditeur}

CIRAC

\section{Édition imprimée}

Date de publication : 1 mars 2006

ISSN : 1156-8992

\section{Référence électronique}

« Droit européen », Regards sur l'économie allemande [En ligne], 75 | mars 2006, document 1, mis en ligne le 24 avril 2008, consulté le 22 septembre 2020. URL : http://journals.openedition.org/rea/493 ; DOl : https://doi.org/10.4000/rea.493

Ce document a été généré automatiquement le 22 septembre 2020

(c) CIRAC 


\section{Droit européen}

MÄHNER Tobias, Der Europäische Gerichtshof als Gericht

\section{RÉFÉRENCE}

MÄHNER Tobias, Der Europäische Gerichtshof als Gericht, Coll. Beiträge zum Europäischen Wirtschaftsrecht, vol. 32, Duncker \& Humblot, Berlin, 2005, 272 p.

1 La Cour européenne de Justice est-elle seulement un tribunal - au sens où l'entend le droit constitutionnel allemand ? Voilà l'interrogation au cœur de cette thèse présentée en 2005 à l'Université d'Erlangen, qui analyse la Cour sous l'angle de sa légitimité démocratique. (ib) 